\title{
PARTISIPASI MASYARAKAT KOTA MALANG DALAM PENCEGAHAN BENCANA BANJIR
}

\author{
Mohammad Muhibbin*, Umar Said Sugiharto**, Budi Parmono***, \\ *Fakultas Ilmu Hukum Universitas Islam Malang \\ Email : MohammadMuhibbin@gmail.com \\ **Fakultas Ilmu Hukum Universitas Islam Malang \\ Email : umarunisma@gmail.com \\ ***Magister Ilmu Hukum Universitas Islam Malang \\ Email : budiparmono@unisma.ac.id
}

\begin{abstract}
Abstrak
Peristiwa banjir yang terjadi di wilayah di kota Malang Jawa Timur mengakibatkan di beberapa ruas jalan protocol dan rumah warga di kota Malang terendam air. Peristiwa banjir seperti ini akan terus terjadi setiap tahun, apabila penyebab utamanya tidak segera dibenahi secara terencana. Karena itu, identifikasi penyebab banjir perlu dicari dan dirumuskan solusinya secara riil. Secara umum, penyebab utama banjir yang terjadi di kota Malang, selain curah hujan yang tinggi, maraknya perumahan baru (real estat), pusat perbelanjaan modern dan rumah toko (Rukoh) di Kota Malang, dangkalnya saluran pembuangan air (drainase) juga akibat rusaknya hutan- hutan di daerah hulu yang kemudian membawa air bah ke kawasan hilir yang lebih rendah, serta banyaknya lokasi yang seharusnya manjadi ruang terbuka hijau sebagai tempat resapan air justru ditempati bangunan permanen. Terkait dengan hal itu perlu adanya pengkajian ulang terhadap kebijakan yang sudah ada yang dapat mengatasi masalah banjir di kota Malang dan mengoptimalkan partisipasi masyarakat secara terorganisasi untuk dapat mengambil tindakan awal dalam penanggulangan banjir.

Kata kunci: Banjir, bangunan permanen dan partisipasi masyarakat
\end{abstract}

\begin{abstract}
Floods that occurred in the city of Malang, East Java, resulted in several protocol roads and residents' houses in the city of Malang being flooded. Floods like this will continue to occur every year, if the main cause is not addressed in a planned manner. Therefore, it is necessary to identify the causes of flooding and formulate a solution in real terms. In general, the main causes of flooding that occur in the city of Malang, apart from high rainfall, the rise of new housing (real estate), modern shopping centers and shop houses (Rukoh) in Malang City, shallow drains are also due to forest destruction. - forests in the upstream areas which then carry flood waters to lower downstream areas, and many locations that should be green open spaces as water infiltration areas are occupied by permanent buildings. Related to this, it is necessary to re-examine existing policies that can overcome the flood problem in Malang and optimize community participation in an organized manner to be able to take initial actions in flood prevention.
\end{abstract}

Keywords: Flood, permanent building and community participation 


\section{PENDAHULUAN}

Secara geografis kota Malang merupakan kota yang terletak di dataran tinggi yang sekitarnya di kelilingi oleh beberapa gunung, antara lain gunung Anjasmoro, gunung Arjuno, Gunung Argopuro, Gunung Bromo, Gunung Welirang, Gunung Kawi. Ironisnya hampir setiap tahun ketika musim hujan tiba, Kota Malang selalu didatangi bencana banjir, sehingga mengakibatkan hanyutnya dan rusaknya puluhan rumah penduduk dan jalan-jalan protokol terendam banjir. Di antara wilayah kota Malang yang terendam banjir antara lain kelurahan: Lowok waru, Sumbersari, Tlogomas, Madyopuro, Lesanpuro, Kedungkandang, gadang, sukun, Tanjung dan Kasin. Peristiwa banjir seperti ini akan terus terjadi setiap tahun, apabila penyebab utamanya tidak segera dibenahi secara terencana. Oleh karena itu perlu dicari penyebabnya dan dicarikan solusi pencegahan dan penanggulangannya secara nyata, terencana dan terpadu.

Secara umum, penyebab utama banjir di berbagai kota itu, selain akibat rusaknya hutan- hutan di daerah hulu yang kemudian membawa air bah dan tanah ke kawasan hilir yang lebih rendah, juga lebih diperparah dengan banyaknya perkotaan yang tidak mempunyai rencana induk (master plan) yang baik untuk penataan sungai dan drainase. Banyak kota yang kurang menyediakan wilayah resapan seperti hutan kota, taman kota, dan beberapa kawasan yang secara hidrologis mampu menyerap kelebihan air

Karena itu, banjir di berbagai wilayah perkotaan dan pedesaan, bisa dihindari seandainya pemerintah dan masyarakat mempunyai kearifan lokal untuk menjaga taman dan atau hutan kota serta melaksanakan hasil studi dengan perencanaannya yang telah dibuat.

Kawasan perlindungan setempat, seperti daerah yang semestinya menjadi resapan air yang bebas bangunan sampai panjang tertentu, justru ditempati bangunan. Maraknya perumahan baru (real estat), pusat perbelanjaan Modern dan rumah toko (Rukoh) di Kota Malang, saat ini dinilai menjadi penyebab munculnya lokasi-lokasi banjir baru di Kota Malang.

Bencana banjir di wilayah perkotaan dan pedesaan dapat dihindari atau dicegah/ditanggulangi jika pemerintah mempunyai perencanaan tata ruang kota dan wilayah (RT-RW) yang memadai dan mengikut sertakan (partisipasi) 
masyarakat untuk pencegahan atau penanggulangan banjir di wilayahnya masingmasing.

Seringnya bencana banjir di kota Malang perlu diantisipasi oleh Pemerintah Kota Malang dengan mengikut sertakan peran masyarakat agar dapat mengurangi bencana banjir yang mengakibatkan korban harta benda maupun korban manusia. Selama ini usaha yang dilakukan oleh pemerintah kota Malang dengan cara-cara yuridis yaitu dengan dikeluarkannya Peraturan Daerah Tata Ruang Kota dan Wilayah (RT-RW) maupun secara struktural kepada pemeritah di bawahnya (Kecamatan dan kelurahan/desa) belum atau tidak berhasil mencegah terjadinya banjir di kota Malang.

Terjadinya serangkaian bencana banjir dalam kurun waktu yang relatif pendek dan selalu terulang setiap tahunnya menuntut upaya lebih besar untuk mengantisipasinya sehingga kerugian yang ditimbulkannya dapat diminimalkan. Berbagai upaya pemerintah daerah yang masih bersifat struktural (structural approach) ternyata belum sepenuhnya mampu menanggulangi masalah banjir. Demikian pula kebijakan sektoral, sentralistik, dan top-down tanpa melibatkan masyarakat sudah tidak sesuai dengan perkembangan global yang menuntut adanya desentralisasi, demokrasi, dan partisipasi stakeholder terutama masyarakat yang terkena dampak bencana. Dengan demikian, maka penanggulangan banjir yang biasa dilakukan dengan pembangunan fisik semata (structural approach) harus disinergikan dengan pembangunan non fisik (nonstructural approach) yang menyediakan ruang lebih luas bagi munculnya partisipasi masyarakat sehingga tercapai hasil yang lebih optimal. Keterbukaan pemerintah untuk mengkomunikasikan setiap program-program pembangunan serta mengupayakan dan menerima partisipasi masyarakat merupakan prasyarat yang harus dipenuhi.

Sampai saat ini keterlibatan masyarakat dalam proses perumusan kebijakan penyelenggaraan penataan ruang dalam wujud peraturan perundangundangan di kota Malang terkait dengan penanggulangan banjir belum dioptimalkan, sehingga menimbulkan banyaknya pelanggaran pembangunan yang mengakibatkan terjadinya banjir di kota Malang ini.

Sehubungan dengan kegagalan tersebut, untuk penanggulangan dan pencegahan banjir selain dilakukan dengan cara yuridis dan struktural oleh 
Pemerintah Daerah Kota Malang, maka diperlukan adanya partisipasi atau keikut sertaan masyarakat dengan cara membangun atau membuat dan memperbaiki sarana-prasarana serta tindakan nyata untuk mencegah terjadinya banjir di kota Malang.

Dengan peran sertanya (partisipasi) masyarakat, maka pencegahan banjir yang selama ini hanya ditanggulangi dengan pembuatan Peraturan Daerah dan perintah/tugas secara struktural kepada instani bawahan serta pembangunan gorong-gorong atau saluran air, maka untuk selanjutnya cara/teknis pencegahan dan penanggulangan banjir harus diintegrasikan secara nyata yaitu dengan mengikut sertakan (partisipasi) masyarakat supaya memperoleh hasil yang maksimal.

\section{METODE PENELITIAN}

Jenis penelitian yang dilakukan dalam penelitian ini adalah yuridis sosiologis (non doktrinal) yang diawali dengan penelitian doktrinal. Penelitian yuridis sosiologis atau non doktrinal merupakan penelitian berupa studi-studi empiris mengenai proses terjadinya dan mengenai proses bekerjanya hukum (kebijakan penataan ruang) di dalam masyarakat yang berkaitan dengan peristiwa banjir. Penelitian Non Doktrinal ini disebut juga sebagai penelitian Socio Legal Research. $^{1}$

Pendekatan yang digunakan didalam penelitian ini adalah model rational approach, yaitu untuk membangun pemahaman penafsiran sebagai landasan tinjauan kritis terhadap kebijakan penataan ruang. Pemahaman konsep utama ini, adalah ruang yang meliputi wadah daratan, lautan dan udara sebagai satu kesatuan wilayah dan tempat manusia serta mempunyai multi dimensi, maka dalam pemanfaatannya harus mengedepankan asas keadilan, kemanfaatan dan kepastian.

${ }^{1}$ Soetandyo Wignjosoebroto, Hukum dan Metode-metode Kajiannya, Makalah Seminar Sosiologi Hukum Pada Program Pascasarjana UNIBRAW Malang, 1998 hlm. 12 :Lihat juga Bambang Sunggono, Metodologi Penelitian Hukum, Jakarta, PT. Raja Grafindo Persada, 2004, hlm. 42 
Untuk memperoleh data dalam penelitian ini ditempuh dengan menggunakan data primer dan data sekunder. Cara memperoleh data primer adalah dengan mengunakan dua cara, yaitu: 1) Teknik wawancara mendalam (dept interview). 2) observasi (observation). Sedangkan data sekunder diperoleh melalui studi dokumen.

Pekerjaan analisis data dalam penelitian ini adalah mengatur, mengurutkan, mengelompokkan, memberikan kode dan mengategorikannya terhadap catatan atau data lapangan yang diperoleh melalui wawancara (interview), observasi (observation) dan dokumen berupa laporan yang berkaitan dengan fenomena yang terjadi dalam hal terjadinya banjir. Setelah data tersebut diatas terkumpul (pengurutan, pengelompokan dan pengkodean) baik berupa data primer maupun sekunder yang telah dianggap valid maka langkah berikutnya mengkonstruksikan data-data tersebut lewat strategi atau pendekatan yang bertumpu pada logika berpikir induksi konseptualis di satu pihak, dan logika berpikir secara emik dipihak lain. ${ }^{2}$

Analisis berikutnya dilakukan dengan menafsirkan data yang diperoleh secara induksi dan membandingkan, menguji atau memverifikasi dengan teori yang sudah ada. Pembandingan atau pengujian ini dimaksudkan untuk mengkaitkan temuan dengan teori yang mengkaji hal-hal yang menjadi fokus penelitian.

\section{HASIL DAN PEMBAHASAN PENELITIAN}

\section{Gambaran Umum Penataan Ruang di Kota Malang}

Malang merupakan sebuah kota di Jawa Timur. Kota Malang berbatasan dengan Kabupaten Pasuruan disebelah utara, Kabupaten Lumajang di timur, Kabupaten Malang di selatan, dan Kota Batu di barat.

Secara administratif Wilayah Kota Malang terdiri atas 5 kecamatan, 45 kelurahan dan 12 desa. Kelima kecamatan tersebut adalah : Kecamatan Klojen, Kecamatan Blimbing, Kecamatan Sukun, Kecamatan Lowokwaru, dan Kecamatan Kedungkandang. hlm. 53-54

${ }^{2}$ Lexy Moleong, 1996, Metode Penelitian Kualitatif, Bandung, Remaja Rosdakarya, 
Kota Malang memiliki luas $124.456 \mathrm{Km}$ persegi serta dihuni oleh 700.000 warganya. Kepadatan penduduk mencapai 5.000 - 12.000 jiwa per kilometer persegi dengan tingkat pertumbuhan 3,9\% pertahun.

Dalam fisiografi Jawa Timur, termasuk dalam zona Pegunungan Selatan yang terdiri dari dataran tinggi yang dikelilingi oleh perbukitan dan pegunungan. Beberapa puncak pegunungan tersebut diantaranya adalah gunung Anjasmoro, Gunung Arjuno di bagian utara, Gunung Kawi dan Gunung Batok di bagian Barat, serta Gunung Semeru dan Gunung Bromo di bagian Timur. Lereng-lereng perbukitan tersebut, umumnya membentuk perbukitan yang kian melandai mendekati Kota Malang. Lembah-lembah yang terbentuk di antara pegunungan umumnya menyempit, cukup dalam dengan tebing curam hingga terjal dan berbentuk V. Pada dasar lembah-lembahnya terdapat alur-alur sungai yang merupakan anak-anak sungai Brantas yang melintasi Kota Malang membujur dari arah Barat-Utara menuju ke arah Selatan Kota.

Banyak gelar ditujukan pada kota Malang seperti Paris of East Java, gelar ini diberikan karena kondisi alamnya yang indah, iklimnya yang sejuk dan bersih, bagaikan kota "Paris"-nya Jawa Timur. Selain itu dijuluki pula sebagai "kota pendidikan", predikat demikian tidak lain situasi kota yang tenang, penduduknya ramah, harga makanan yang relatif murah dan fasilitas pendidikan yang memadai sangat cocok untuk belajar/menempuh pendidikan. Sedikitnya ada lima perguruan tinggi negeri berdiri di kota Malang : Universitas Brawijaya, Universitas Negeri Malang, Universitas Islam Negeri Malang, Politeknik Negeri Malang, Politeknik Negeri Kesehatan Malang dan puluhan Perguruan Tinggi Swasta.

Selama 10 tahun terakhir ini perkembangan fisik bangunan pada umumnya telah berkembang dengan pesat, namun perkembangan tersebut tidaklah dapat dirasakan merata di seluruh pelosok kota. Terjadi pertumbuhan pembangunan fisik yang terpacu dengan pesat di sisi Utara dan Barat hingga menembus wilayah Kabupaten Malang, sementara di sisi lain perkembangan pembangunan fisik berjalan lambat yaitu pada sisi Timur dan Selatan kota. Akibatnya terjadi penumpukan beban pergerakan pada wilayah yang berkembang pesat dan hal ini menyebabkan terjadinya inefisiensi dalam pergerakan lalu lintas sehari-hari. Salah satu contoh adalah pembangunan mega mal yakni MATOS (Malang Town 
Square) yang dianggap karya monumental oleh pemerintah daerah, dibangun di kawasan Barat dilingkungan pendidikan yakni ada TK, SD, SMP, SMU, serta Perguruan Tinggi. Pembangunan mega mall yang diresmikan tanggal 26 Mei 2005 telah menyisahkan renungan warga masyarakat kota Malang agar tidak terulang lagi pembangunan Mal seperti itu. Jika ditelusuri perkembangan daerah resapan air di wilayah Kota Malang, antara lain yang ada di belakang Musium Brawijaya dan saluran sementara yang membentang disepanjang jalan Jakarta jalan Gede dan jalan Pulosari, sudah hilang namun pada kenyataannya telah berdiri kawasan permukiman mewah dan juga terdapat beberapa pertokoan di belakang Musium Brawijaya. Dengan demikian Kota Malang yang dahulu tidak pernah banjir, saat ini fenomena yang terjadi adalah apabila musim penghujan datang, jalan menjadi tergenang dan di beberapa tempat terjadi banjir (walaupun banjir ini hanya sebentar, menunggu pengaliran air hujan ke anak-anak sungai yang ada), seperti di daerah Stadion Gajayana, di jalan Raya Ijen, jalan Pulosari, jalan Patimura, daerah perumahan Sawojajar, jalan Sukarno Hatta, dan sebagainya.

\section{Pengertian Banjir}

Banjir merupakan fenomena alam yag terjadi karena derasnya hujan yang terjadi di kawasan yang banyak aliran sungai. Dalam Kamus Besar Bahasa Indonesia disebutkan bahwa banjir diartikan sebagai air banyak dan deras karena hujan terus menerus yang mengalir melalui sungai sehingga meluap ke luar sungai sehingga membenamkan daratan (tanah kering) sekitarnya. ${ }^{3}$ Sedangkan banjir bandang adalah banjir yang besar yang mengalir deras sebagai air bah yang meluap dan menggenangi tebing sungai maupun daratan di sekitar sungai yang melanda tanaman, pepohonan, perladangan/persawahan dan pemukiman penduduk, bahkan dapat menimbulkan korban nyawa manusia dan harta benda. Banjir juga diartikan sebagai datangnya air di suatu kawasan luas sehingga menutupi kawasan permukaan bumi tersebut. Di dalam Peraturan Dirjen RLPS No. 04 Tahun 2009 menjelaskan, banjir adalah aliran air yg relatif tinggi, yang tidak tertampung oleh alur sungai atau saluran air, atau karena debit aliran air di sungai secara relatif lebih besar dari kondisi normal akibat hujan yang turun di

\footnotetext{
${ }^{3}$ Kamus Besar Bahasa Indonesia, Pusat Bahasa, Edisi ke IV, jakarta, PT Gramedia Pustaka utama, 2008, hlm.135
} 
hulu atau suatu tempat tertententu yang terjadi secara terus menerus, sehingga air tersebut tidak dapat ditampung oleh alur sungai yg ada, maka air melimpah ke luar dan menggenangi daerah sekitarnya. Singkatnya banjir adalah meluapnya air sungai ke luar sungai melampaui tebing sungai yang disebabkan oleh banyaknya dan derasnya hujan yang terus menerus, sehingga aliran sungai tidak dapat menampung air hujan yang deras dan banyak.

Dengan demikian banjir merupakan peristiwa di mana daratan yang biasanya kering menjadi tergenang oleh air, hal ini disebabkan oleh curah hujan yang sangat tinggi dan kondisi topografi wilayah berupa daratan rendah hingga cekung. Selain itu, terjadinya banjir juga dapat disebabkan oleh limpahan air permukaan yang meluap dan volumenya melebihi kapasitas pengaliran sistem drainase atau sistem aliran sungai. Terjadinya banjir juga disebabkan oleh rendahnya kemampuan infiltrasi/penyerapan tanah sehingga menyebabkan tanah tidak mampu lagi menyerap air. Banjir dapat juga terjadi akibat naiknya permukaan air lantaran curah hujan di atas normal, perubahan suhu, tanggul/bendungan jebol, dan terhambatnya aliran di tempat lain. ${ }^{4}$

Adapun penyebab yang terjadi di kota Malang adalah akibat tidak ada resapan air. Banjir jenis ini diakibatkan karena tanah/daratan tidak mampun menyerap air (karena tanahnya padat, karena tanahnya lembab, karena tidak mempunyai resapan air). Banjir ini merupakan banjir yang terjadi akibat curah hujan yang tinggi dan airnya berlebihan sehingga meluap dan menggenangi wilayah daratan. Dalam hal ini terjadinya bajir lokal sangat tinggi.

\section{Faktor-Faktor Penyebab Terjadinya Banjir Di Kota Malang.}

\subsection{Perumahan dan Mall Sebagai Penyebab Munculnya Lokasi-Lokasi Baru Banjir di Malang}

Maraknya perumahan baru di Kota Malang, saat ini dinilai menjadi penyebab munculnya lokasi-lokasi banjir baru di Kota Malang. Demikian disampaikan Kepala Dinas Pemukiman Sarana dan Prasarana Wilayah (Kota

${ }^{4}$ Ligal, Pendekatan Pencegahan Banjir, Jurnal "Dinamika Teknik Sipil, Vol. 2 Juli 2008. Hlm. 54. 
Kimpraswil) dan kondisi yang ada sekarang di wilayah kota malang muncul lokasi-lokasi banjir baru di Kota Malang. Dari hasil penelitian, nampaknya terjadinya banjir-banjir baru tersebut disebabkan tidak adanya outlet atau saluran keluar air dari sistem drainase.

Kebutuhan perumahan baru ini akan selalu ada. Sementara biasanya perumahan-perumahan itu bergantung pada saluran drainase utama yang telah ada. Logikanya kalau dengan curah hujan yang sama tetapi beban saluran drainase bertambah, maka air akan meluber dan terjadilah genangan atau banjir. Untuk itu diperluakan perangkat hukum yang perlu direspon Pemerintah Kota Malang untuk membuat peraturan daerah (perda) mengenai layout kawasan. Dalam perda itu seyogyanya termuat kajian drainase lingkungan. "Apakah lingkungan tersebut akan meresapkan air yang ada hanya 10 persen sementara yang dialirkan 90 persen dan sebaliknya, sehingga terjadi keseimbangan antara resapan air dari curah hujan yang tinggi dengan keadaan lingkungan yang ada di sekitar wilayah tersebut. Yang lebih penting lagi adalah adanya peraturan daerah itu akan menentukan dengan jelas siapa yang berhak menerbitakan atau mengesahkan site plan atau lay out suatu kawasan yang akan dibangun.

Selama ini site plan kawasan di Kota Malang terkait sistem drainasenya menurut Kimpraswili belum jelas. Tidak ada arahan yang jelas mengenai arahan sistem drainase bangunan baru. Akibatnya semua membebani saluran drainase utama. "Inilah yang membuat persoalan banjir di Kota Malang tidak pernah selesai.

Pemerintah Kota mengakui, saat ini Kimpraswil masih menyisakan 12 lokasi banjir dari 25 lokasi yang selama ini ditangani. Ke-12 lokasi banjir itu menurutnya akan segera diselesaikan tahun ini. Lokasi-lokasi banjir tersisa untuk digarap Kimpraswil antara lain pertigaan Jalan Ahmad Yani, perempatan ITN, Jalan Veteran depan MATOS, dan sebaginya. "Rata-rata selain karena tersumbat sampah, di lokasi-lokasi itu terjadi penyempitan saluran drainase karena munculnya bangunan-bangunan baru. Lain lagi dengan apa yang disampaikan anggota Dewan Kota malang, yang mengatakan kalau memang masih terjadi 
banjir di Kota Malang, itu artinya program perencanaan di Kota Malang tidak tepat. Maksudnya bahwa konstruksi dari gorong-gorong yang sudah dibetulkan tidak pas. Sehingga air bisa kembali melimpah. Demikian apa yang disampaikan oleh Dewan Perwakilan Rakyat Daerah (DPRD) Kota Malang Komisi C (bidang pembangunan), Pujianto. Menurutnya, perlu perencanaan banjir di Kota Malang yang lebih tepat dan efektif.

Dengan pesatnya pembangunan di Kota malang yang tentunya terjadi berubahan fungsi tanah yang sedianya menjadi kawasan ruang terbuka hijau menjadi tegakan bangunan-bangunan yang kokoh, termasuk "Panorama Square" semakin menguatkan indikasi akan berubahnya predikat kota Malang sebagai “Kota Mall”, bukan lagi “Kota Pendidikan Internasional” seperti yang selama ini didengung-dengungkan pemuka civitas akademika di kota ini. Masih teringat jelas, bagaimana aktifis dari berbagai Universitas di kota ini menolak dengan keras pembangunan Malang Town Square, dilanjutkan dengan adanya mega proyek "Malang Olympic Garden" dengan dalih "hanya" untuk menyambut even Liga Champion Asia, dan sekarang, "Panorama Square". Pemerataan perekonomian adalah alibi pemerintah kota. Memang benar, dengan pembangunan "Panorama Square" akan "meratakan" peta perekonomian di Malang, tidak lagi berpusat di tengah kota Malang, tetapi juga di Malang Utara. Pembangunan seperti inilah yang mengakibatkan terjadinya banjir di Kota Malang

Pemerintah kota sendiri pun sepertinya lebih memprioritaskan perizinan pembangunan Malang Olympic Garden, Panorama Square, dan lain-lain yang menyangkut prestise kota Malang. Betapa sebuah ironi jika nantinya Malang mendapat Adipura namun masih didapati banjir disana-sini apalagi di tempat yang dekat sekali dengan kawasan hijau Jalan Ijen. Seharusnya, pemerintah kota juga harus memperhatikan keseimbangan daerah resapan, sehingga bisa diminamilisir atau bahkan dihilangkan "budaya" banjir di kota Malang. Disadari, penanggulangan banjir tidak hanya bisa dilakukan jika hanya melibatkan satu atau dua instansi pemerintahan saja. Oleh karenanya yang perlu dilakukan adalah pemulihan mental masyarakatnya terlebih dahulu, bagaimana masyarakat disadarkan tentang pentingnya turut serta menanggulangi banjir. 
Melihat fenomena di atas, merupakan suatu paradoks dari asas dan tujuan penataan ruang. Prinsip efisiensi menyatakan bahwa: ruang yang ada harus dimanfaatkan secara optimal sejalan dengan nilai ekonomisnya. Sedangkan prinsip equity atau pemerataan menyatakan bahwa: pemanfaatan ruang harus memperhatikan nilai-nilai sosial, terutama untuk menjamin kemungkinan akses yang setara bagi masyarakat untuk memanfaatkan ruang sebagai sumber utama pembangunan. Relokasi pemukiman-pemukiman kumuh untuk supermarket, hotel, perumahan mewah ataupun perkantoran dalam beberapa segi menunjukkan kepentingan efisiensi yang berlebih di atas kepentingan pemerataan atau equity. ${ }^{5}$

Fakta kongkrit dari permasalahan perebutan ruang (spasial) di atas nampak munculnya masalah seperti:

a. Mulai terlihat adanya pergeseran lahan pertanian yang subur menjadi tempat industri.

b. Terjadinya pola-pola penggunaan lahan yang bercampur (mixed used) antar sektor industri dengan sektor kegiatan sosial ekonomi lain dengan karakteristik yang bertolak belakang.

c. Mulai ditemukannya kasus-kasus pencemaran lingkungan dan beberapa aliran sungai sudah terkontaminasi limbah-limbah cair yang berbahaya. Demikian pula kualitas udara ambient yang sudah berubah yang cenderung menimbulkan "rumah kaca".

d. Timbulnya daerah-daerah kumuh (slum area) di sekitar pusat-pusat kegiatan industri, terutama disebabkan perencanaan kegiatan industri tidak diikuti dengan perencanaan perumahan buruh maupun jasa penunjang lainnya.

Oleh karena itu peran serta masyarakat sangat diperlukan untuk penanggulangan banjir. Peneliti teringat dengan 3M nya KH. Abdullah Gymnastiar, “ Mulai dari diri sendiri, Mulai dari yang terkecil, dan, Mulai dari sekarang.“. Ya, kita tidak perlu muluk-muluk mencanangkan sebuah program (yang terkesan) nirlogika, mulailah dari sekarang memanage diri sendiri tentang pentingnya sebuah kebersihan, mulailah membuang sampah di tempatnya saja

${ }^{5}$ Imam Kuswahyono, Bunga Rampai Politik Dan Hukum Agraria Di Indonesia, Penerbit IKIP Malang, 2000, hlm 94 
dulu, dan yang terpenting, mulailah dari sekarang. Maka niscaya akan terbentuk sebuah lingkungan yang sehat, dan semoga, bebas banjir.

\subsection{Minimnya Ruang Terbuka Hijau, Penggundulan hutan, Resapan Air dan Sempitnya Gorong-Goraong/ Drainase di Kota Malang}

Barangkali sekarang, refleksi mendasar mengenang Malang di masa lalu adalah bagaimana melacak jejak kesejarahan perjalanan Malang di masa lalu yang dikaitkan dengan potret Malang sekarang? Apa yang membuat perbedaan mendasar Malang di masa lalu dengan Malang dewasa ini dan bahkan di masa mendatang?

Membandingkan Malang di era 1980-an, sekurang-kurangnya peneliti memasuki dan berkenalan dengan wilayah Malang, tentulah sangat berbeda dengan sekarang. Di tahun 80-an ini, Malang masih dingin sekali. Untuk beradaptasi dengan iklim dingin ini butuh waktu berbulan-bulan. Bahkan kalau kita jalan-jalan di malam hari, nyaris tidak ada pencari hiburan ini yang tidak mengenakan jaket atau pakaian tebal untuk menahan hawa dingin.

Iklim yang sangat dingin itu dipengaruhi oleh kondisi geografis Malang yang selain diapit dengan pegunungan, juga masih luasnya kawasan persawahan, resapan air, dan banyaknya pohon berdiri dimana-mana. Ketika musim hujan tiba, saat itu kondisi Malang benar-benar sangat dingin. Meski demikian, nyaris mustahil kita temukan genangan air di jalan-jalan, apalagi sampai terjadi banjir. Resapan air masih ada dimana-mana, sehingga air tidak sampai "menghiasai atau membanjiri jalanan" dan rumah-rumah penduduk.

Kondisi itulah yang sekarang tidak kita temukan lagi di Malang, selain dewasa ini suhu udara di Malang sangat panas, setiap kali musim hujan tiba, di berbagai wilayah di Malang tergenang banjir. Dalam kondisi hujan agak deras saja, di beberapa tempat dan jalur strategis seperti jalan Sokarno Hatta, Borobudur, MT Harjono, dan lainnya, sudah menjadi kawasan "langganan banjir jalanan”. Bahkan di beberapa rumah penduduk yang berada di pinggir jalan, sudah "mulai terbiasa" dirambah banjir.

Sekarang setiap kali datang musim hujan, di hati pengguna jalan pun dilanda kegamangan atau perasaan miopik, pasalnya, bukan hanya kemacetan 
yang harus dihadapi, tetapi jalanan yang dibanjir air juga membuat pengguna jalan harus menjadikannya sebagai "tantangan serius" yang harus disikapinya, yang bisa berdampak pada kerusakan kendaraan jika tidak cermat dan sabar dalam mengemudikannya.

Beberapa tahun belakangan ini, berita banjir sudah terbiasa menghiasi media massa, atau di setiap kali musim hujan, identik dengan berita mengenai bencana alam di Malang. Hari ini hujan lebat misalnya, besoknya koran sudah mewartakan berbagai bentuk peristiwa mulai dari pohon tumbang dan rumah penduduk yang rusak berat akibat bencana banjir.

Tahun 2007 misalnya, banjir melanda sebagian wilayah di kota Malang akibat hujan deras yang mengakibatkan ratusan rumah terendam banjir dan ketinggian air mencapai dua meter. Banjir di kota Malang ini mengakibatkan sekitar 111 rumah warga di lima kelurahan terendam air luapan Sungai Amprong. Kelurahan tersebut masing-masing Kelurahan Madyopuro, Lesanpuro, Kedung Kandang, Mergosono dan Kelurahan Kota Lama.

Bencana banjir di Malang seperti itu hanya sampel yang mengkritik keras terjadinya perbedaan paradoksal dalam pola pembangunan di Malang. Perbedaan ini "mewajibkan" masyarakat Malang menanggung akibatnya. Perbedaan yang bercorak paradoksal ini tidak lepas dari model pembangunan kawasan Malang yang tergolong sangat "radikal" atau bahkan revolusioner. Malang telah diubah wajahnya oleh pemerintah maupun pemodal kuat menjadi kawasan industrialisasi perktokoan, mall, hiburan, rumah susun, atau disulap sebagai kawasan perbelanjaan yang menyeret masyarakat menjadi konsumtif dan larut dalam pusaran kehidupan yang mengedepankan pesona dunia hiburan.

Model pembangunan Malang yang mengejar target terwujudnya industrialisasi perbelanjaan telah memakan "ongkos" yang tidak murah, yang biaya ini bukan ditanggung oleh pemerintah dan pemilik modal kuat, tetapi oleh masyarakat yang menerima resiko buruknya akibat hilangnya kawasan Ruang Terbuka Hijau (RTH), yang nota bene sebagai wiyalah resapan air.

Dari hasil penelitian menunjukkan bahwa Ruang terbuka hijau di Kota Malang hanya tinggal empat persen dari seluruh luas wilayah yang mencapai 110,06 kilometer persegi. Sedangkan lahan resapan air hanya tinggal 40 persen. 
Kondisi Ini sudah di ambang batas dan menyalahi aturan pemerintah. PP No 63/2002 sudah menggariskan, bahwa luas RTH itu minimal 10 persen dari luas wilayah masing-masing kabupaten/kota

Ruang terbuka hijau di Kota Malang tercatat hanya tersisa seluas 3.188 hektare atau 2,89 persen dari luas wilayah keseluruhan. RTH itu terinci taman atau hutan kota seluas 12 hektare, sempadan sungai 80 hektare, tanah pekarangan dan kebun 150 hektare, dan sawah 2.940 hektare.

Semakin menipis atau habisnya kawasan RTH tersebut jelas sebagai akar masalah serius yang menjadikan Malang sekarang berbeda dengan "Malang Tempoe Doloe". Malang di tahun 80-an masih memiliki "kekayaan" istimewa berupa luasnya RTH, sementara Malang sekarang sedang menjadi "Malang yang malang" akibat dilanda "kemiskinan" RTH.

"Kemiskinan" RTH itulah yang membuat Malang sekarang memiliki "kekayaan" baru saat musim hujan tiba yang bernama banjir atau kalau musim kemarau tiba, suhu di kota Malang semakin panas. Kondisi ini tentulah tidak boleh dibiarkan berlarut-larut, pasalnya jika kondisi ini semakin berlarut, dikhawatirkan di kemudian hari (saat musim hujan datang), Malang akan tenggelam atau semakin berhiaskan bencana banjir dimana-mana, yang membuat Malang benar-benar bertambah malang.

Mengandalkan APBD untuk "melawan" atau membebaskan Malang dari banjir bencana atau bencana banjir, memang dapat membantu, tetapi anggaran ini lebih bercorak penyembuhan, dan bukan membedah akar masalahnya. Bahkan kalau anggaran ini tidak banyak atau kurang berfungsi maksimal, juga tidak bisa diaharapkan banyak. Revitalisasi gorong-gorong dan pembenahan daerah aliran sungai sudah dilakukan oleh Pemkot Malang. Upaya lain yang bisa dilakukan oleh pemerintah daerah diantaranya dengan mengendalikan "syahwat" mengembangkan atau membiakkan pembangunan yang bercorak industrialisasi hiburan dan perbelanjaan yang jelas-jelas berelasi dengan kebutuhan atas lahan atau tanah.

Kalau sisa tanah atau RTH di Malang ini masih akan terus diproyeksikan oleh pemerintah guna memenuhi "syahwat" kalangan pemilik modal atau menopang akselerasi bisnis kalangan berduit, masyarakat Malang layak lebih 
khawatir lagi kalau Malang di kemudian hari hanya tinggal tuyang-tuyang yang patut dikenang layaknya kota Seribu Satu Malam, yang sekedar dijadikan dongeng bagi anak-anak yang hendak menuju peraduan (tidur).

Pemkot Malang, ujar Poedjiono, mempunyai keyakinan gorong-gorong di Kota Malang akan mampu mengatasi banjir jika difungsikan dengan baik. Namun, sayang sekali hingga saat ini cetak biru gorong-gorong Kota Malang ada di Belanda. "Pemkot sudah meminta blue print gorong-gorong di Kota Malang dari Belanda. Namun, hingga kini orang Belanda yang diharapkan bisa membantu mengfungsikan kembali gorong-gorong masih belum datang,"

Ahli Drainase Perkotaan Universitas Brawijaya, Agus Suharyanto menyangkal gorong-gorong akan mampu mengatasi banjir di Kota Malang. Menurut Agus, gorong-gorong tetap tak akan mampu menampung air karena daerah resapan air semakin berkurang. "Air yang tidak teresap tanah semakin banyak sehingga gorong-gorong tak akan mampu menampung," katanya. Yang harus dimaksimalkan Pemkot Malang adalah membersihkan saluran pembuangan air atau avore yang ada.

Selain hal tersebut di atas, maraknya perumahan baru (real estat), pusat perbelanjaan modern dan rumah toko (Ruko) di kota Malang, saat ini dinilai menjadi penyebab munculnya lokasi-lokasi banjir baru di kota Malang. Hal itu disebabkan adanya bangunan-bangunan tersebut nampaknya tidak ada outlet atau saluran air dari sistem drainase.

\section{MODEL PARTISIPASI MASYARAKAT UNTUK MENCEGAH BANJIR}

\section{Partisipasi Masyarakat}

Partisipasi dari bahasa Inggris "participation" artinya pengambilan bagian atau pengikutsertaan, dan "participate" artinya mengikutsertakan, atau mengambil bagian. Dalam Kamus Besar Bahasa Indonesia "Partisipasi" berarti turut serta atau turut berperan dalam suatu kegiatan, atau keikutsertaan. ${ }^{6}$ Menurut Keith Davis, partisipasi adalah suatu keterlibatan mental dan emosi seseorang kepada pencapaian tujuan dan ikut bertanggung jawab di dalamnya. Partisipasi juga

\footnotetext{
${ }^{6}$ Kamus Bahasa Indonesia, Op., cit, hlm 1024
} 
berarti "pembuat keputusan dari masyarakat kelompok atau masyarakat ikut serta terlibat dalam bentuk penyampaian saran dan pendapat, barang, ketrampilan, bahan dan jasa. ${ }^{7}$ Dengan demikian pengertian partisipasi masyarakat adalah keikutsertaan masyarakat atau pengambilan bagian oleh masyarakat dalam proses mengidentifikasi dan penyelesaian masalah yang ada di masyarakat. Singkatnya partisipasi masyarakat ialah keikutsertaan masyarakat dalam proses penyelesaian permasalahan yang dihadapi oleh masyarakat itu sendiri, mulai dari pengidentifikasian, pemilihan, dan pengambilan keputusan masyarakat selalu berperan aktif.

Adapun pengertian partisipasi masyarakat dalam pembangunan adalah berperansertanya masyakat termasuk semua anggota atau wakil-wakil masyarakat untuk ikut membuat keputusan dalam proses perencanaan dan managemen pembangunan termasuk di dalam merumuskan dan memutuskan rencana-rencana kegiatan yang akan dilaksanakan, manfaat yang akan diperoleh, dan juga bagaimana melakukan evaluasi hasil pelaksanaannya. Adanya partisipasi yang maksimal dari masyarakat dalam perencanaan diharapkan dapat membangun rasa kepemilikan yang kuat di kalangan masyarakat terhadap hasil-hasil pembangunan yang ada.

Dari pendapat tersebut dapat disimpulkan bahwa partisipasi masyarakat adalah keterlibatan dan pelibatan anggota masyarakat dalam pengelolaan pembangunan yang terjadi di masyarakat. Partisipasi masyarakat seyogyanya berlangsung secara sukarela dan keberlanjutan. Partisipasi yang dimaksud adalah partisipasi yang memandang masyarakat sebagai subyek dari segala aturan dan pembangunan bukan sebagai obyek pembangunan.

\section{Model Partisipasi Masyarakat Dalam Penanggulangan Banjir}

Pencegahan banjir di kota Malang bukan hanya monopoli pemerintah daerah saja, tetapi juga masyarakat harus ikut terlibat atau ikut berpartisipasi, karena yang menjadi korban dan mengalami kerugian akibat banjir adalah masyarakat dan Pemerintah Daerah. Masyarakat mengalami kerugian harta benda (rumah, tempat usaha/industri, tanah pertanian, hewan ternak) ikut terbawa arus juga korban jiwa. Selain itu kerugian yang dialami oleh pemerintah adalah

${ }^{7}$ Fasli Djalal dan Dedi Supriadi, Reformasi Pendidikan Dalam Konteks Otonomi Daerah, Yogyakarta, Adicita Karya, 2001, hlm 25 
rusaknya jalan-jalan dan sarana serta prasarananya di wilayahnya karena tergerus oleh banjir.

Model pencegahan banjir (dilakukan sebelum banjir) dan penanggulangan (dilakukan pada saat terjadi/sesudah banjir), oleh Pemerintah Daerah, adalah dengan cara, pertama membuat peraturan/ aturan hukum (regulasi) yang mengatur ttg perencanaan tata ruang kota dan wilayah. Dalam peraturan tersebut yang diatur adalah (a) penataan tata ruang perkotaan yakni pengaturan terhadap penentuan wilayah/area pemukiman/hunian penduduk; area usaha/industri kecil, area pertokoan, area pendidikan, area pariwisata, peternakan, area pertanian, area ruang terbuka hijau (RTH), area ruang terbuka hijau (ruang terbuka) minimal disediakan 20-30 \% dalam wilayah perkotaan.; (b) Regulasi/aturan tentang IMB dan Usaha kecil, menengah dan industri bersekala besar; (c) Regulasi tentang larangan mendirikan bangunan dan tempat usaha/jualan di tempat RTH, diatas sungai/selokan atau tempat aliran/saluran air sungai/air hujan, tanah-tanah milik di Negara/Pemda; (d) Regulasi tentang larangan menutup halaman rumah/kantor pemerintah/perusahaan swasta, dan bahu/tepi jalan/di luar pagar rumah/bangunan dengan semen/beton/aspal; (e) Regulasi tentang larangan membuang sampah di sembarang tempat (sungai, parit/selokan atau tempat saluran air ke sungai, dan di jalan raya). Kedua, secara struktural Pemda hendaknya mempersiapkan tenaga terlatih untuk pencegahan dan penanggulangan banjir di setiap desa/kelurahan; Pemda harus mengusahakan pemenuhan/menambah tempat-tempat resapan air sesuai yang ditentukan oleh UU Tata Ruang dan Wilayah dan Peratuan Kementerian Dalam Negeri minimal 20-30 \% ; Ketiga pemerintah daerah hendaknya mempersiapkan sarana dan parasarana untuk pencegahan dan penanggulangan banjir agar setiap diperlukan sudah tersedia; Keempat mengikut sertakan dan mendidik masyarakat untuk mencegah terjadi banjir, antara lain : (a) melarang masyarakat membuang sampah di daerah aliran sungai/parit/selokan; (b) melarang masyarakat mendirikan bangunan di atas aliran sungai/selokan/parit; (c) melarang masyarakat menutup aliran sungai yang ada di sekitar/rumah/bangunan miliknya; (d) menghimbau masyarakat untuk tidak menutup tanah resapan/serapan air di sekitarnya, baik di tanah milik pribadi atau milik/yang dikelola oleh pemerintah/swasta; (e) melarang masyarakat melakukan penebangan 
pohon hutan lindung/pepohonan di daerah resapan air hujan dan menghimbau kepada masyarakat unruk melakukan penanaman pohon dalam rangka menahan abrasi tanah; Kelima melakukan penindakan hukum berupa pemberian sanksi denda, administratif, dan penindakan/pembongkaran bangunan terhadap/ masyarakat yang melanggar peraturan/Regulasi yang dibuat oleh Pemerintah Pusat/Pemerintah Daerah.

\section{Tindakan Pencegahan dan Penanggulangan Banjir}

Oleh karena kota Malang merupakan daerah pegunungan yang jauh dari laut, maka banjir di kota malang bukan banjir yang disebabkan oleh banjir rob yang umumnya terjadi di daerah pantai. Banjir di Kota Malang umumnya disebabkan karena meluapnya air sungai jika terjadi hujan lebat sehingga menimbulkan banjir dadakan. Selain itu disebabkan oleh kurangnya daerah resapan/serapan air,hal ini disebabkan terjadinya alih fungsi lahan yang berubah menjadi hunian atau pemukiman baru dengan banyaknnya dibangun perumahan, tempat-tempat hiburan/pariwisata, pembangunan tempat indutri dan perdagangan (mall/supermarket), dan banyaknya masyatakat membangun tempat usaha dan rumah di tepi sungai yang dapat mengakibatkan pendangkalan dan penyempitan aliran sungai. Selain itu hampir semua tempat resapan/serapan air baik itu milik pemerintah daerah maupun masyarakat ditutup dengan aspal/semen.

Untuk mengatasi dan mencegah terjadinya banjir di kota Malang, usaha atau tindakan yang dapat dilakukan oleh Pemda dan masyarakat kota Malang adalah sebagai berikut:

a. Menjaga lingkungan sekitar sungai, selokan atau parit supaya terjaga dengan baik. Jangan sampai masyarakat membuang sampah di saluran atau aliran sungai, atau jangan sampai selokan dan parit dijadikan tempat pembuangan sampah;

b. Hindari membuat bangunan/rumah di tepi sungai, karena hal ini dapat menyebabkan terjadinya banjir, dan tatanan masyarakat menjadi tidak teratur dan kumuh (daerah menjadi kumuh);

c. Melakukan program tebang pilih dan reboisasi. Pohon yang ditebang hendaknya pohon yang sudah tua atau rawan tumbang. Pohon yang ditebang sebaiknya ada penggantinya, tujuannya untuk regenerasi pohon supaya hutan 
tidak menjadi gundul sebagai tempat untuk menghimpun air di hutan, sehingga air hujan tidak langsung turun ke dataran rendah yang berakibat banjir;

d. Membuat gerakan membuang sampah pada tempatnya. Hindari membuang sampah sembarangan, terutama membuang sampah ke sungai atau aliran ke sungai karena dapat brdampak buruk yaitu sampah yang menumpuk di aliran atau saluran sungai yang dapat menyumbat aliran air sungai sehingga mengakibatkan banjir. Untuk menghindari pembuangan sampah di sembarang tempat atau di sungai, perlu disediakan tempat pengelolaan dan dan pengolahan sampah.

e. Rajin membersihkan tempat saluran atau aliran air ke sungai. Perbaikan dan pembersihan saluran air harus dilakukan secara gotong royong yang melibatkan masyarakat setempat secara rutin atau terus menerus. Tujuannya adalah apabila terjadi hujan deras, air tidak akan tersumbat, sehingga air dapat mengalir dengan lancar ke sungai dan muara sungai yang akhirnya ke laut.

\section{PENUTUP}

Berdasarkan uraian diatas maka dapat ditarik kesimpulan sebagai berikut :

1. Terjadinya banjir di Kota Malang dapat dipengaruhi oleh beberapa faktor, antara lain:

a. Kesadaran masyarakat Kota Malang membuang sampah sangat rendah, sehingga dapat menyumbat saluran air menuju gorong-gorong.

b. Maraknya pembangunan rumah-rumah baru (real estat) dan pusat perbelanjaan modern yang tidak diimbangi dengan sistem drainase yang cukup

c. Terjadinya alih fungsi lahan yang seharusnya menjadi kawasan Ruang Terbuka Hijau (RTH) dan daerah resapan air justru berubah menjadi areal pembangunan.

2. Partisipasi masyarakat sebagai salah satu stakeholder sangat diperlukan dalam upaya membendung terjadinya bencana banjir. Menjadikan masyarakat sebagai subyek yang memiliki peran bersama dengan pemerintah mulai dari proses dan implementasi kebijakan yang dibuat oleh pemerintah dalam penataan ruang yang ada di kota Malang merupkan sebuah keharusan yang harus dilaksanakan 
dalam penanggulanagan bencana banjir. Partisipasi masyarakat memiliki pengaruh sangat besar dalam proses dan implementasi kebijakan.

Dalam rangka menyusun rekomendasi kebijakan, partisipasi masyarakat dalam kegiatan penanggulangan banjir, perlu ditetapkan lebih cermat tingkat partisipasi pada setiap tahap kegiatan, sesuai dengan jenis kegiatan penanggulangan banjir. Untuk merumuskan strategi partisipasi, juga diperlukan pengelompokan kegiatan penanggulangan banjir atas dasar:

1. Besarnya dampak langsung maupun tidak langsung yang akan diterima masyarakat;

2. Jumlah dan keragaman penerima dampak kegiatan;

3. Intensitas biaya sosial dari suatu kegiatan yang akan diterima oleh masyarakat.

Perumusan partisipasi masyarakat tidak dapat dilakukan tanpa mencermati posisi dan urgensi stakeholder lainnya, seperti intermediaries dan decision/policy maker. Dari sudut pandang tingkat partisipasi stakeholder, ada batasan bahwa tidak semua kegiatan penanggulangan banjir dapat dilakukan oleh seluruh stakeholder sampai ke tingkat empowerment. Semakin banyak pihak yang terlibat, akan terlalu banyak kepentingan yang harus diakomodasi dan terlalu banyak jalur birokrasi antar sektor, sehingga proses koordinasi lintas sektor dan pelaksanaan kegiatan (development) sangat mungkin menjadi terhambat, bahkan batal. Dengan demikian tingkat ketertarikan (interest), pengaruh (influence), dan kepentingan (importance) setiap stakeholder harus diidentifikasi lebih dahulu agar bisa ditentukan sejauh mana stakeholder tersebut dilibatkan.

\section{DAFTAR PUSTAKA}

Bambang Sunggono, 2004, Metodologi Penelitian Hukum, Jakarta, PT. Raja Grafindo Persada.

Fasli Djalal dan Dedi Supriadi, 2001, Reformasi Pendidikan Dalam Konteks Otonomi Daerah, Yogyakarta, Adicita Karya,

Imam Kuswahyono, 1999, Bunga Rampai Politik Dan Hukum Agraria Di Indonesia, Penerbit IKIP Malang.

Kamus Besar Bahasa Indonesia, 2008, Pusat Bahasa, Edisi ke IV, Jakarta, PT Gramedia Pustaka utama,

Ligal, 2008, Pendekatan Pencegahan Banjir, Jurnal "Dinamika Teknik Sipil, Vol. 2 Juli . Lexy Moleong, 1996, Metode Penelitian Kualitatif, Bandung, Remaja Rosdakarya 
Sanapiah Faisal, 1990, Penelitian Kualitatif (Dasar-Dasar Aplikatif), Malang, Yayasan Asih Asah Asuh.

Undang-Undang NO. 26 Tahun 2007 tentang Penataan Ruang, Bandung,Citra Umbara, Wignjosoebroto, Soetandyo, 1998, Hukum dan Metode-metode Kajiannya, Makalah Seminar Sosiologi Hukum Pada Program Pascasarjana UNIBRAW. 